\title{
MECHANICAL STRENGTH CHARACTERISTICS OF BIO CONCRETE WITH TWO DIFFERENT BACTERIA
}

\author{
RITESH KUMAR $^{1}$ \& ADITYA TIWARI ${ }^{2}$ \\ ${ }^{I}$ M. Tech, Chandigarh University, India \\ ${ }^{2}$ Assistant Professor, Chandigarh University, India
}

\begin{abstract}
Since a long time concrete has been a very important part of the construction and with time, concrete faced many problems and got solutions with time. But one biggest problem with the concrete is 'crack', that has been part of construction for a long time. Many remedies were provided to protect the construction components but to regain the original strength after crack propagation is a little hard task. Then the concept solution was invented by the researchers for this problem was 'Bacterial Concrete'. This work is related to the analysis of the mechanical strength characteristics of bacterial concrete embedded with two different bacteria. Mainly the compressive strength, tensile strength, and flexural strength of the bacterial concrete are verified in the presence of two different bacteria.

KEYWORDS: Bio-Concrete, Bacterial-Concrete, Healing, Cohnii Bacteria
\end{abstract}

Received: Jun 09, 2020; Accepted: Jun 29, 2020; Published: Jun 30, 2020; Paper Id.: IJMPERDJUN2020299

\section{INTRODUCTION}

The life of construction has been started a long time ago and the marvellous examples have been presented there since an unrevealed past history. We have forts around us from recent history and pyramid from a long period of history. Later on, with the help of the concrete, today we stand with the advanced versions of the construction in the play of high rise towers, unique shaped buildings and the residential places. With the history of construction, we came to know that, one very panicking problem that sticks with concrete is crack propagation in the most construction elements i.e. roofs, walls, ceiling floors etc. Every problem comes with a solution and for this problem, many researchers were ready to attack to this crack situation with various types of solutions. Unfortunately, after ample of remedies and solutions we have reach in an era where now, the most effective solution for this crack problem can be Bacteria. A lot of studies already have been done and still are going on to search for a bacterium which can fill or heal the crack instantly as it appears. To verify the precipitation of the calcite from the bacteria,[1] this paper worked on a spore forming bacteria. The spores of these bacteria were capable of resisting the alkali effect and were related to the bacillus genuses which have been proved a famous and efficient delivery for the purpose of crack healing. The spores of the bacteria were directly put in to the cement paste and were left in there for the time sake of 4 months for colonization and viability purpose.

The main purpose of using the spores is not to prevent the crack, that is inevitable, but to fill the crack with the nearby same strength as it has earlier though regaining the actual strength is not possible till now. Whoever have been thought to restart the hydration process after cement is absent inside. Here [2] author gave a trial to this thought with the bacillus sphaericus which is a part of Bacillus genus. Paper shows the working of this bacteria same as cement i.e. similarly precipitate calcite, but the main process includes the urea that later get converted into 
ammonia and carbonate. whatever but his results were fulfilled as promised and the bacteria was able to precipitate crystal hence helpful to heal crack and to support his work author performed ample of tests that are described in his paper wisely.

Working with bacteria is not an easy task though we know bacteria is working same as cement works in concrete but to use these bacterial spores in the cement mixture and into concrete was a very big problem. But wise people never stop chasing the solution and here [3] worked with capsules embedded with crack filling agent. The beauty of capsule is, it could carry the healing agent for long than we expected and when crack appears it starts working. Happily, this technique worked well and results showed the strength regaining more than the half percentage. Researchers moving forward step by step and with this capsule solution we got our control on strength also. Fortunately, this technique helped to reduce the permeability to some extent, and that was an additional achievement by the author.

Working with capsules with healing agent was fascinating but there were many more things about capsules to work on. Researchers now started working with microcapsules and found plenty of obstacles i.e. the effect of the capsules on mixture. Here [4] author wanted to observe the reaction process of microcapsule with the cement component. Researcher used the spores of bacteria inside the capsules and performed the SEM test for verification of breaking capsules. Because if crack appears and capsule does not break, then that is useless to use such capsules but test verified breakage and it was an optimistic performance of microcapsules with spores. Also with the help of healing ratio, technique was showing more than seventy percentages regaining of strength. Even the crack width filed with this technique was unbelievable and amazing as it was nearby four times.

Hence the work of Bactria with the cement and concrete is a coming future and a possible solution to treat the crack. Many researchers have worked on various obstacles but the discovery of bacteria will never stop. In this research work, mainly bacteria spores are mixed with the concrete and verification of mechanical strength is done because even if bacteria show any positive outcome related to healing of crack but not compatible with the concrete and its mechanical strength, then that is useless in performance. Our priority of work here is to mix bacteria with water in the concrete and see if the mechanical strengths are not affected after 7, 14 and 28 days. Two bacteria were used in this work for comparison purposes are Enterobacter sp and bacillus cohnii.

\section{MATERIALS}

\section{Bacteria Sample}

One of the bacteria was used for this research work was characterized as Enterobacter sp. This bacterial strain used in the present study was isolated and purified using Pikovskaya's agar (Himedia, Mumbai) from the rhizospheric soil of Punjab. The pure colony of bacteria was used for mass cultivation of the strain. $500 \mathrm{ml}$ of the Nutrient broth (Peptone- $10 \mathrm{~g} / \mathrm{L}$, Beef extract- $10 \mathrm{~g} / \mathrm{L}$, Sodium chloride- $510 \mathrm{~g} / \mathrm{L}, \mathrm{pH}-7.0 \pm 0.1$ ) was prepared and autoclaved at $120{ }^{\circ} \mathrm{C}$ for 15 minutes. After the media reached to room temperature, $100 \mu \mathrm{l}$ of pure inoculums was transferred to it in the sterile conditions. The inoculated media was incubated at $28{ }^{\circ} \mathrm{C} \pm 1$ for $24 \mathrm{hrs}$ and used for the study. The bacteria were characterized and identified using various biochemical tests that were performed according to the Bergey's Manual of systematic bacteriology. Final characterization of bacteria was done by $16 \mathrm{~S}$ ribosomal DNA (RNA) sequencing method. 


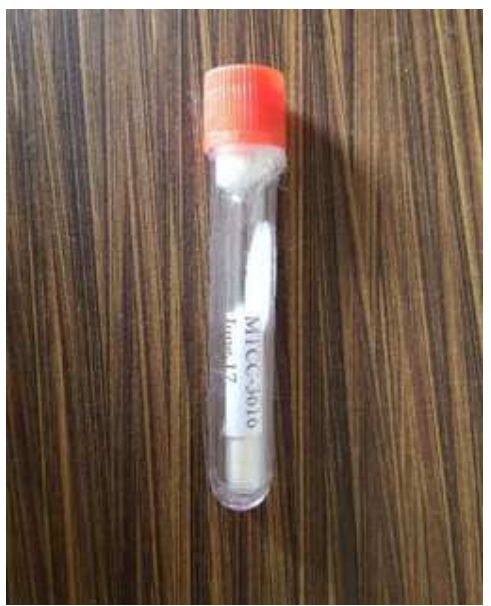

Figure 1: A Cohnii Bacterium was Delivered by the Agency in the Container.

The Bacillus cohnii (MTCC No. 3616) was purchased from Institute of Microbial Technology (IMTECH), Chandigarh [Fig. 1]. The freeze-dried bacterial culture from ampoules was revived as soon as it was received. For this, the ampoule was disinfected with $70 \%$ ethanol. The neck of the ampoule was broken in the laminar air flow. $100 \mu$ l of sterilized Nutrient broth was added to the ampoule and mixed thoroughly using a sterile pipette. The culture was used to inoculate the sterile $100 \mathrm{~mL}$ nutrient broth. The inoculated media was incubated at $37^{\circ} \mathrm{C} \pm 1$ for 48 hrs and used for further experimentation.

\section{Concrete Specimen}

To calculate the mechanical strength of the concrete specimen, mainly three tests were performed i.e. compression test, flexural test and tensile test. To perform the all the above tests, the bacterial sample mixed with water as $10 \mathrm{ml}$ of bacterial sample into the $1000 \mathrm{ml}$ of water. Two types of the specimen were casted to compare the effect of the bacteria on the concrete mechanical strength i.e. conventional specimen and controlled specimen. To cast the conventional specimen, no bacteria was added and no other treatment was applied on the them. Though when control specimens were casted bacteria sample was added to the water in ratio 1:100. Control specimen are classified as Control Specimen A and Control Specimen B. [Fig. 2] In which specimen Enterobacter Sp. was added into the water during the casting, that is named as Control Specimen A and in which specimen cohnii bacteria was added into the water during casting, that is named as Control Specimen B.

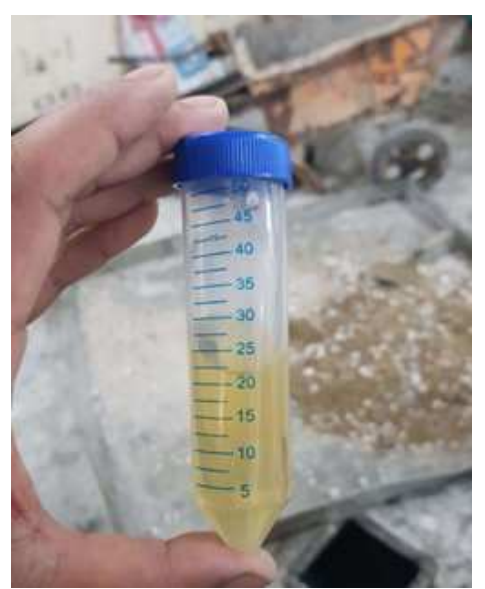

Figure 2: After the Reviving Process Bacteria was Added in the Liquid Form. 
Concrete grade used for casted was M30 grade. Ordinary Portland cement was used in the concrete mixing with sand and coarse aggregates after adding the bacteria in water, the concrete ingredients were mixed with good care. All the ingredients were taken as per required proportion.

\section{METHODS\& PROCEDURES}

\section{Bacterial Extraction}

The detailed procedure of the both bacteria has been described in the previous section. In addition, bacterial portion is the most important of this work as it will be helping the concrete to stand for a longer time by eliminating the crack problem.

\section{Mechanical Test}

To perform the compression test, [Fig. 3] total nine cube specimens were casted of the dimension $150 \mathrm{~mm} * 150 \mathrm{~mm} * 150 \mathrm{~mm}$. Similarly, for the flexural test, [Fig. 4] total nine beams were casted of the dimension $500 \mathrm{~mm} * 100 \mathrm{~mm} * 100 \mathrm{~mm}$. Similarly, for the tensile test, total nine cylinders were casted of the size $300 \mathrm{~m}$ height and $150 \mathrm{~mm}$ diameter. For each of tests, out of nine, three specimens were casted for 7 days testing, three specimens were casted for 14 days testing and three specimens were casted for 28 days testing. After casting the specimens, they were kept at room temperature. After 24 hours, casted specimens were demoulded and kept in the water storage tank. For the testing, specimens were taken out and tested accordingly after 7 days, 14 days and 28 days. Average values were noted after testing three samples for each test.

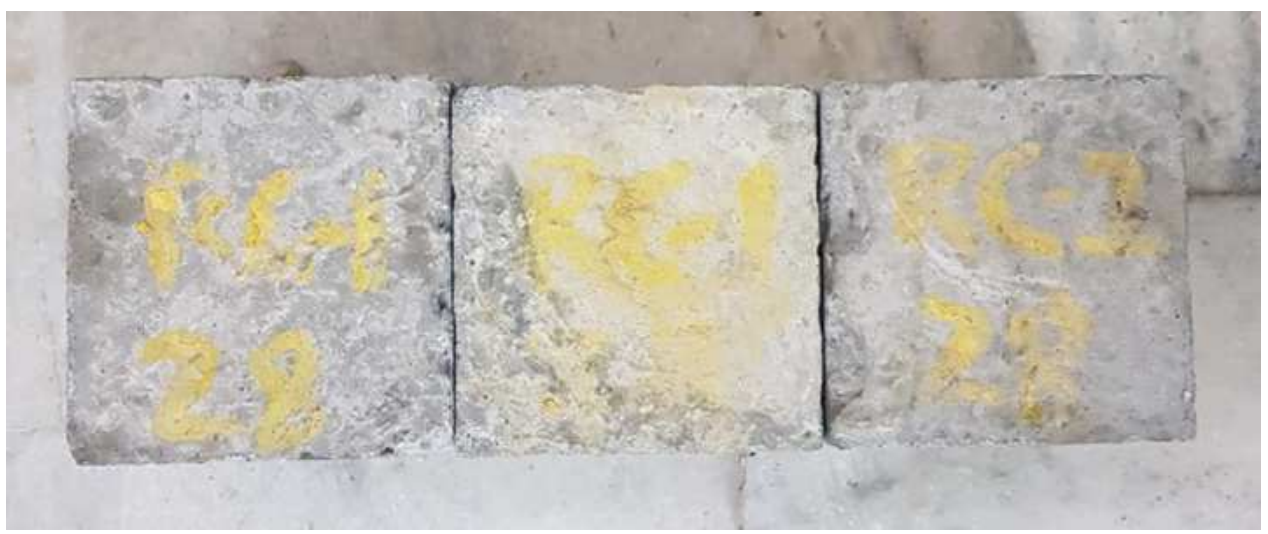

Figure 3: Control Specimen Cubes are Presented in the Above Pictures Before the Testing.

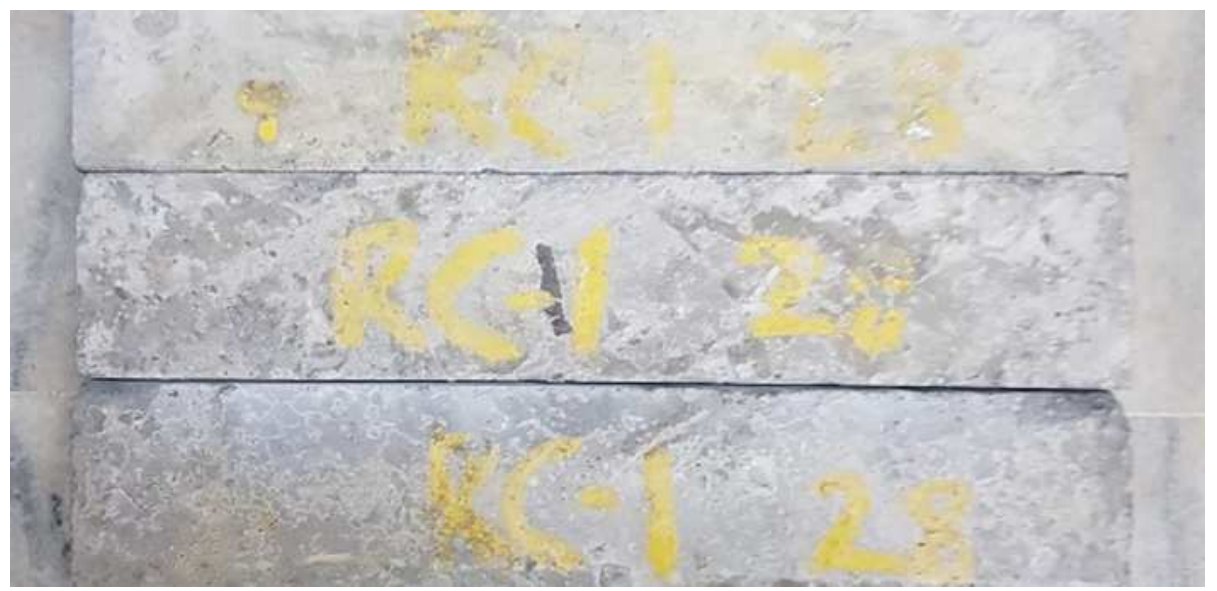

Figure 4: Control Specimen Beams are Shown in Above Pictures Before the Testing. 


\section{RESULTS DISCUSSIONS}

\section{Compressive Strength}

Working with the bacteria and concrete is always a unpredictable process. Compressive strength is one of the most important parameter of the mechanical strength. The effect of the both bacteria on the concrete as compared to conventional concrete has been shown in the graph. Here [Fig. 5], the conventional specimen is showing less strength as compared to control specimen A and control specimen B after 7 days. This proves the optimistic reaction of the both bacteria on concrete as it is improving the strength after 7 days. Though after 14 days, all three specimens are showing the almost same strength. But after the 28 days testing, it is observed that control specimen A is showing little less strength as compared to conventional specimen. Also the control specimen B is observed as showing much more less strength as compared the conventional concrete. Altogether this can be seen as a positive result because in all the testing, all the strengths are not that much affected.

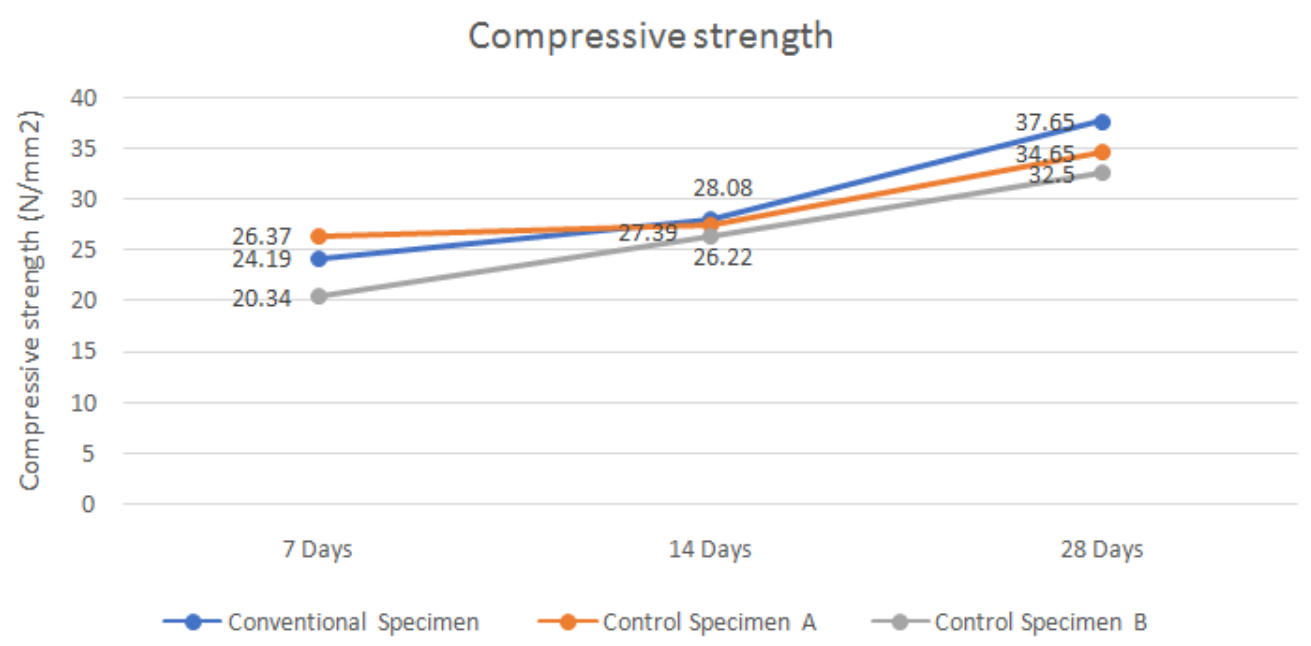

Figure 5: Compressive Strength Test Results After 7, 14 and 28 Days Testing of the Conventional Specimen. Control Specimen A and Control Specimen B are Presented in with the Help of Graph.

\section{Flexural Strength}

In the graph [Fig. 6], all the results of flexural test are presented and it is clearly observed that strength of all three specimens i.e. conventional specimen, control specimen A and control specimen B, is almost close to each other. So the effect of any bacteria on the concrete is not negative. All the three specimens show the almost equal flexural strength after 7 days, 14 days and 28 days. Though the effect of bacteria is not noticeable on the flexural strength, does not mean bacteria will not show any effect on the other mechanical strengths also. Among the flexural strength and other mechanical strengths, mostly, compressive strength is the most dominant mechanical strength of the concrete that is considered. 


\section{Flexural Strength}

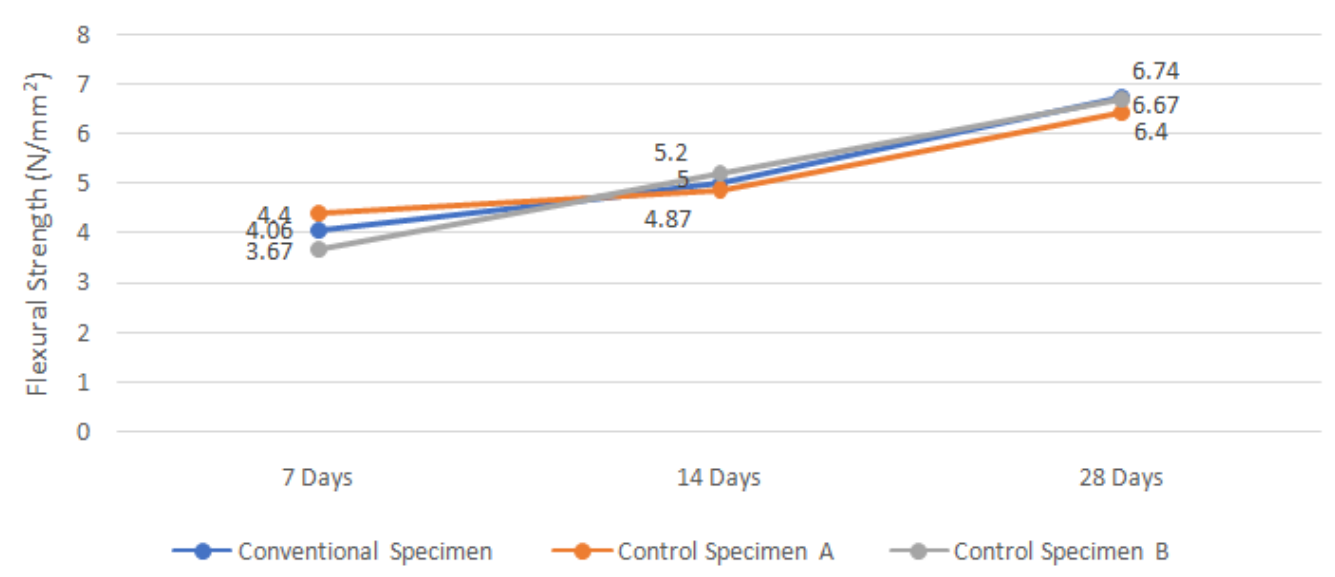

Figure 6: Flexural Strength Test Results After 7, 14 and 28 Days Testing of the Conventional Specimen, Control Specimen A and Control Specimen B are Presented in with the Help of Graph.

\section{Tensile Strength}

Similar to flexural strength, the effect of the both bacteria on the concrete tensile strength is not noticeable or it can be put as a positive response. Results of the testing after 7 days, 14 days and 28 days are presented with the help of graph [Fig. 7]. Conventional specimen and control specimen A testing results after 7 days almost similar so it can be illustrated that Enterobacter Sp. dose not show any negative effect on the tensile strength of concrete after 7 days testing. Similarly, after 14 days testing, conventional specimen ad control specimen A are showing same strength but after 28 days testing, there is little difference in the tensile strength of the both specimen but that is acceptable. On the other hand, the tensile strength of the control specimen B is showing lesser value as compared to conventional specimen after the 7 days testing, 14 days and 28 days. However, the strength of control specimen B on 28 days testing is not that much varied. But results exhibits that the cohnii bacteria is affecting the concrete from the starting of hardening process.

\section{Tensile Strength}

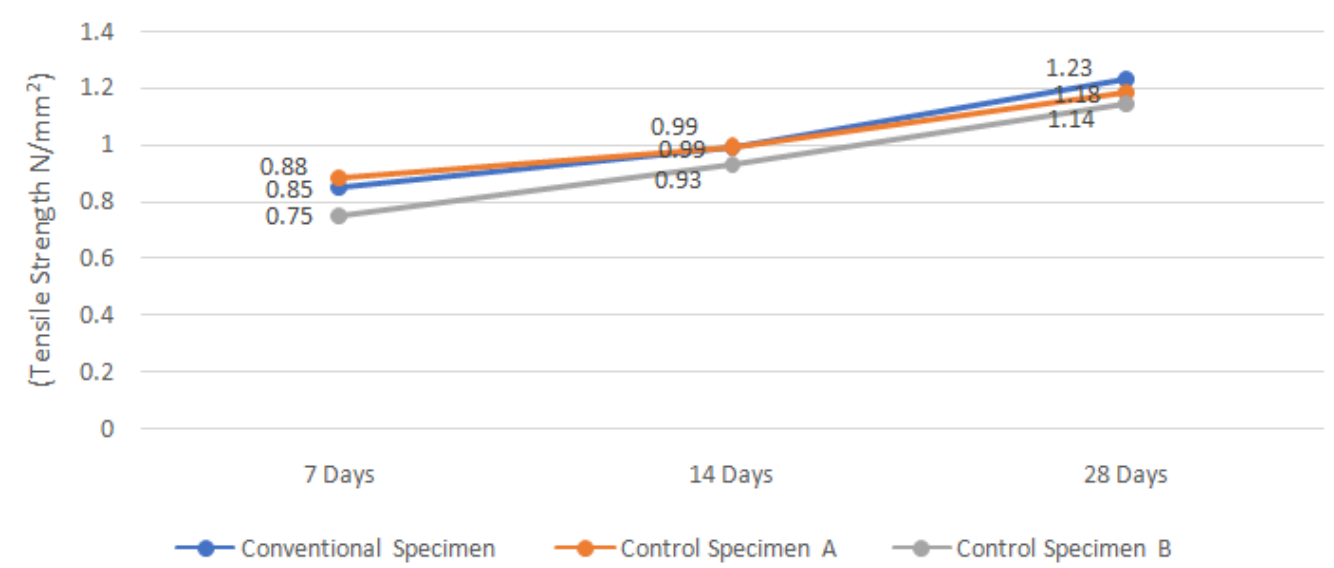

Figure 7: Tensile Strength Test Results After 7, 14 and 28 Days Testing of the Conventional Specimen. Control Specimen A and Control Specimen B are Presented in with the Help of Graph. 


\section{CONCLUSIONS}

Various tests carried out to experience the effect of two bacteria on the concrete behaviour. Most of the conclusive results are as follows:

- After the analysis of compressive strength test results, it was observed that after 7 days, 14 days and 28 days testing' improvement in the strength of control specimen A was approx. 18.9\%, 7.09\% and 15.8\% consecutively and of control specimen B was $29.64 \%, 4.46 \%$ and $6.61 \%$ consecutively.

- Flexural strength test results have not revealed much improvement in the strength due to presence of any bacteria in the concrete.

- After the analysis of tensile strength test results, it was observed that after 7 days, 14 days and 28 days testing' improvement in the strength of control specimen A was approx. 13.33\%, $6.45 \%$ and $7.89 \%$ consecutively and of control specimen B was $17.33 \%, 6.45 \%$ and $3.50 \%$ consecutively.

\section{REFERENCES}

1. Jonkers H M, Thijssen A, Muyzer G, et al. Application of bacteria as self-healing agent for the development of sustainable concrete. Ecol Eng 2010; 36: 230-235.

2. Van Tittelboom K, De Belie N, De Muynck W, et al. Use of bacteria to repair cracks in concrete. Cem Concr Res 2010; 40: 157-166.

3. Van Tittelboom K, De Belie N, Van Loo D, et al. Self-healing efficiency of cementitious materials containing tubular capsules filled with healing agent. Cem Concr Compos 2011; 33: 497-505.

4. Wang JY, Soens H, Verstraete W, et al. Self-healing concrete by use of microencapsulated bacterial spores. Cem Concr Res 2014; 56: 139-152.

5. Luo M, Qian CX, Li RY. Factors affecting crack repairing capacity of bacteria-based self-healing concrete. Constr Build Mater 2015; 87: 1-7.

6. Zhang J, Liu Y, Feng T, et al. Immobilizing bacteria in expanded perlite for the crack self-healing in concrete. Constr Build Mater 2017; 148: 610-617.

7. Kalhori $H$, Bagherpour $R$. Application of carbonate precipitating bacteria for improving properties and repairing cracks of shotcrete. Constr Build Mater 2017; 148: 249-260.

8. Alghamri R, Kanellopoulos A, Litina C. Preparation and polymeric encapsulation of powder mineral pellets for self-healing cement based materials. Constr Build Mater 2018; 186: 247-262.

9. Хи J, Wang X. Self-healing of concrete cracks by use of bacteria-containing low alkali cementitious material. Constr Build Mater 2018; 167: 1-14.

10. Sidiq A, Gravina RJ, Setunge S, et al. Microstructural analysis of healing efficiency in highly durable concrete. Constr Build Mater 2019; 215: 969-983.

11. Su Y, Feng J, Jin P, et al. Influence of bacterial self-healing agent on early age performance of cement-based materials. Constr Build Mater 2019; 218: 224-234.

12. Tsangouri E, Gilabert FA, De Belie N, et al. Concrete fracture toughness increase by embedding self-healing capsules using an integrated experimental approach. Constr Build Mater 2019; 218: 424-433. 
13. Nain N, Surabhi R, Yathish N V., et al. Enhancement in strength parameters of concrete by application of Bacillus bacteria. Constr Build Mater 2019; 202: 904-908.

14. Abdulkareem M, Ayeronfe F, Majid MZA, et al. Evaluation of effects of multi-varied atmospheric curing conditions on compressive strength of bacterial (bacillus subtilis) cement mortar. Constr Build Mater 2019; 218: 1-7.

15. Meshram, Diwesh, et al. "Algae Fuel Technology-Concept of Revolutionary Future." Research and Development (IJAERD) 3.3 (2013): 15-28.

16. Al-Zamily, Raji T N, Amaal K G Al-Assadi, and Mohammed A S Issa. "Production of single cell oil by local isolate of Mucor species using by-products as carbon and nitrogen sources and determination of fatty acids profile." International Journal of Agricultural Science and Research (IJASR) 6.1 (2016): 309-320.

17. Mohamad, S H Marzety Adibah Al Sayed, and Zakaria Mohammad. "Using Expressive Art Therapy in the Healing Process of Delinquent Adolescents." International Journal of Humanities and Social Sciences (IJHSS) 4.2 (2015):1-12

18. Dinesh, K. "Analysis of Mechanical Strength for Nanosized Scandia Doped Dispenser Cathodes." International Journal of Mechanical and Production Engineering Research and Development (IJMPERD) 8.1 (2018):803-806 